\title{
Desempenho de um filtro anaeróbio de fluxo ascendente como unidade de tratamento para efluente de suinocultura
}

\author{
Performance of a up-flow anaerobic filter as a treatment unit for suinoculture \\ effluent
}

\author{
Priscila de Castro Silva ${ }^{1}$ \\ Cláudio Milton Montenegro Campos ${ }^{2}$
}

\section{Resumo}

Este estudo avaliou o desempenho de um filtro anaeróbio de fluxo ascendente, operando no tratamento de efluentes da suinocultura. $\mathrm{O}$ sistema foi monitorado por meio de análises físico-químicas laboratoriais e a quantificação do biogás foi estimada teoricamente por meio da DQO. Foram coletadas amostras compostas do afluente e efluente do filtro anaeróbio. As análises físico-químicas realizadas foram: temperatura, $\mathrm{pH}$, alcalinidade, acidez total, sólidos totais, fixos e voláteis, sólidos suspensos, dissolvidos, DQO (total e filtrada), $\mathrm{DBO}_{5}$, fósforo total e NTK. A temperatura média do efluente líquido foi de $22,7^{\circ} \mathrm{C}$ e os tempos médios de detenção hidráulica (TDH) do filtro foram de 94,7 e 63,1 horas, durante a partida e após a mesma. O sistema de tratamento apresentou eficiência de $72,14 \%$ para a remoção da $\mathrm{DBO}_{5}$, com concentração efluente de $281,5 \mathrm{mg} \mathrm{L}^{-1}$.Para a remoção da DQO total e filtrada, os valores percentuais foram de 67,08 e 70,57\%, respectivamente, correspondente a 791,9 $\mathrm{mg} \mathrm{L}^{-1}$ e $233 \mathrm{mg} \mathrm{L} \mathrm{m}^{-1}$. As concentrações de alcalinidade do afluente e efluente foram 1142,8 $\mathrm{mg} \mathrm{L}^{-1}$ e $644,8 \mathrm{mg}$ $\mathrm{L}^{-1}$, relação AI/AP de 0,28 e pH efluente 7,5. A eficiência de remoção para Nitrogênio Total Kjeldahl foi de 33,1\%, para fósforo total $24,2 \%$. A eficiência na remoção de sólidos totais, fixos e voláteis foi de 29,9; 21,5 e 37,4\%, respectivamente. O sistema de tratamento foi eficiente, por conseguinte os parâmetros operacionais praticados poderão ser empregados para sistemas em escala plena.

Palavras-chave: digestão anaeróbia; biogás; $\mathrm{DBO}_{5}$; $\mathrm{DQO}_{\text {total }}$; alcalinidade de ripley; remoção de sólidos.

\section{Abstract}

This study evaluated the performance of an upflow anaerobic filter, operating in swine effluent treatment. The system was monitored by means of laboratorial physico-chemical analyzes and the biogas quantification was theoretically estimated by means of DQO.

1 Dra.; Engenharia de Biomateriais; Universidade Federal de Lavras, UFLA, Brasil; ENVIAR OCUPAÇÃO ATUAL, LOCAL E ENDEREÇO DE OCUPAÇÃO;

2 Dr.; Environmental Engineering; UNIVERSITY OF NEWCASTLE UPON TYNE - UK, NUT, Inglaterra; Professor Titular do Departamento de Engenharia (DEG) - Núcleo de Engenharia Ambiental da Universidade Federal de Lavras- FLA; Endereço: Universidade Federal de Lavras, Departamento de Engenharia, Engenharia de Água e Solo. Universidade Federal de Lavras - Campus Universitário - Departamenteo de Engenharia, Campus Universitário. CEP: 37200000 - Lavras, MG - Brasil; E-mail: cmmcampos@deg.ufla.br

\begin{tabular}{llllll}
\hline Ambiência & Guarapuava (PR) & v.14 n.3 & p.561-578 & Set/Dez 2018 & ISSN $1808-0251$
\end{tabular}


Composite samples were collected from the affluent and effluent from the anaerobic filter. The physical-chemical analyzes were: temperature, $\mathrm{pH}$, alkalinity, total acidity, total solids, fixed and volatile, suspended solids, dissolved, DQO (total and filtered), $\mathrm{DBO}_{5}$, total phosphorus and NTK. The mean liquid effluent temperature was $22.7^{\circ} \mathrm{C}$ and the mean hydraulic detention times (TDH) of the filter were 94.7 and 63.1 hours, during and after startup. The treatment system presented efficiency of $72.14 \%$ for the removal of $\mathrm{DBO}_{5}$, with an effluent concentration of $281.5 \mathrm{mg} \mathrm{L}^{-1}$. For the removal of the total DQO and filtered the percentage values were 67.08 and $70.57 \%$, respectively, corresponding to $791.9 \mathrm{mg} \mathrm{L}^{-1}$ and $233 \mathrm{mg} \mathrm{L}^{-1}$. The alkalinity concentrations of the tributary and effluent were $1142.8 \mathrm{mg} \mathrm{L}^{-1}$ and $644.8 \mathrm{mg} \mathrm{L}^{-1}$, AI / AP ratio of 0.28 and effluent $\mathrm{pH}$ 7.5. The removal efficiency for Kjeldahl Total Nitrogen was 33.1\%, for total phosphorus $24.2 \%$. The efficiency of removal of total, fixed and volatile solids was 29.9; 21.5 and $37.4 \%$, respectively. The treatment system was efficient, so the operational parameters practiced could be used for full scale systems.

Keywords: anaerobic digestion; biogas; $\mathrm{BOD}_{5}$; $\mathrm{COD}$; ripley alkalinity; solids removal

\section{Introdução}

A importância da suinocultura reside, não só no amplo número de criadores envolvidos, mas também no volume de empregos gerados, direta e indiretamente e pela capacidade de produzir grande quantidade de proteína de alta qualidade em área reduzida e em curto espaço de tempo, em comparação com outras espécies de animais de médio e grande porte (CABRAL et al., 2011).

O suíno é um animal monogástrico, e cerca de 30\% ou mais dos seus alimentos ingeridos tornam-se dejetos com concentração de nutrientes elevada. O esterco líquido dos suínos contém matéria orgânica, nitrogênio, fósforo, potássio, cálcio, sódio, magnésio, manganês, ferro, zinco, cobre e outros elementos contidos nas dietas dos animais, sendo grande parte liberada nas excretas (CAMPOS et al., 2005). Devido à enorme quantidade e digestibilidade dos nutrientes fornecidos na dieta, os dejetos suínos possuem elevado potencial causador de poluição ambiental. Tais efluentes quando lançados em corpos d'água, provocam a morte de peixes e interferem no equilíbrio de outras formas de vida aquática.

Os principais componentes dos dejetos de suínos que deterioram as águas superficiais já foram mencionados em pesquisas realizadas por Diesel et al. (2002). Entre eles, podemos citar: a matéria orgânica, nutrientes, bactérias fecais, sedimentos e excesso de nutrientes. Em se tratando de poluição atmosférica causada pela suinocultura, Blanes-Vidal et al.,(2009) ressalvam que isto ocorre em função da liberação de odores derivados de gases mercaptanos oriundos da decomposição.

Por mais de um século, o processo anaeróbio vem sendo utilizado no tratamento de efluentes. Neste processo, a degradação da matéria orgânica biodegradável ocorre por meio de bactérias anaeróbias, na ausência de oxidante externo, gerando o biogás. A anaerobiose ocorre em inúmeros meios naturais e em espaços controlados como digestores anaeróbios (CHENICHARO, 1997).

O processo de digestão anaeróbia pode ser afetado por fatores como o substrato e condições de operação. Fatores ambientais importantes no controle da digestão anaeróbia são a temperatura, o $\mathrm{pH}$, a composição química do efluente, a presença de nutrientes, a competição das metanogênicas com as bactérias redutoras de sulfato e a presença de materiais tóxicos (BITTON, 1994; VAN HAANDEL; LETTINGA, 1994). 
Diante disso, o objetivo deste trabalho foi avaliar o desempenho da digestão anaeróbia de efluente proveniente de suinocultura, em filtro anaeróbio de fluxo ascendente cujo meio suporte utiliza anéis de Pall confinados em malhas plásticas, para torná-los cada vez mais vantajosos como solução de alta relação benefício/custo para tratamento de esgotos no Brasil.

\section{Material e métodos}

\section{Material}

O experimento foi realizado dentro da caixa de vegetação na área de tratamento de efluentes da suinocultura do Departamento de Zootecnia, no campus da Universidade Federal de Lavras, Lavras, MG. As análises físico-químicas foram realizadas no Laboratório de Análise de Água do Departamento de Engenharia da UFLA.

\section{Métodos}

\section{Variáveis do processo}

Para partida, foi empregado como inóculo o lodo anaeróbio granulado volume de $21 \mathrm{~L}$ de um reator UASB, concentração de sólidos voláteis totais de 32,8 $\mathrm{g} \mathrm{L}^{-1}$ e carga orgânica biológica de $1 \mathrm{~kg} \mathrm{DBO}_{5} \mathrm{~kg} \mathrm{SVT} \mathrm{d}{ }^{-1}$. A vazão empregada na partida foi de $21 \mathrm{~L} \mathrm{~d}^{-1}$, resultando em TDH de 100,4 h. A alimentação do sistema foi por fluxo contínuo. O período de monitoramento do sistema de tratamento de efluentes foi feito em 142 dias consecutivos, divididos em duas fases.

A fase 1 teve um período de 55 dias, TDH de 94,7 h e COV de $0,41 \mathrm{Kgm}^{-3} \mathrm{~d}^{-1}$ de DQO, com amostras coletadas no turno da manhã; já a fase 2 ocorreu no período de 87 dias, TDH 63,1 h e COV de 0,34 $\mathrm{Kgm}^{-3} \mathrm{~d}^{-1} \mathrm{de} \mathrm{DQO}$, com amostras coletadas em períodos compostos. O efluente foi coletado em frascos no período de $08 \mathrm{~h} 30 \mathrm{~min}$ às $13 \mathrm{~h} 30 \mathrm{~min}$, com intervalos de $2 \mathrm{em} 2$ horas.

Os parâmetros avaliados foram: temperatura, $\mathrm{pH}$, alcalinidade AP/AI/AT, sólidos (totais, fixos, voláteis e suspensos), DQO (total e filtrada), DBO, P total e NTK.

$\mathrm{O}$ aparato experimental do sistema de tratamento está apresentado na Figura 1.

Figura 1 - Diagrama esquemático do sistema de tratamento: (1) tubulação de PVC de condução do afluente à caixa de areia, (2) caixa de areia com o medidor de vazão triangular tipo Thompson, (3) peneira estática, (4) tanque de acidificação e equalização do efluente, (5) bombeamento do efluente peneirado até o filtro anaeróbio, (6) visualizador hídrico de gás, (7) filtro anaeróbio, (8) saída do efluente do filtro anaeróbio

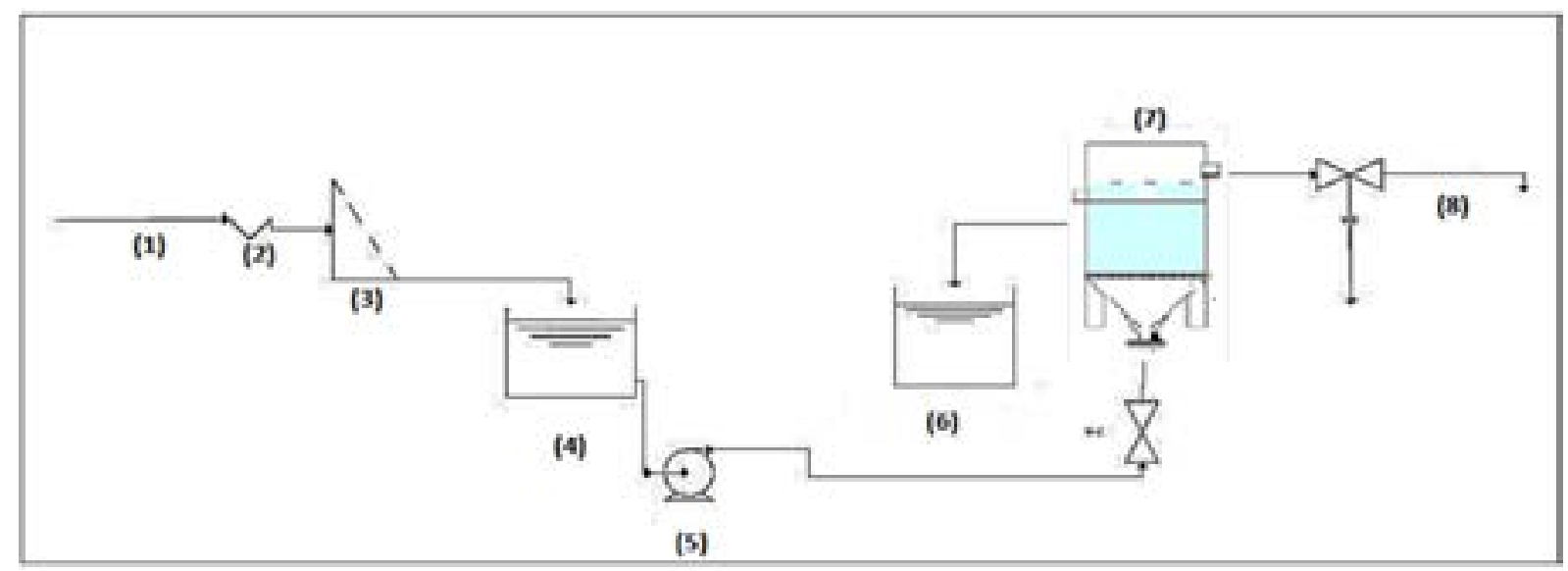

Fonte: próprio autor. 


\section{Determinação da superfície específica}

Para a determinação da superfície específica do meio suporte, cinco amostras foram desmembradas, sendo as partes semicírculos, 2 retângulos diferentes, e triângulos. Cada meio suporte apresentou valor médio de $152,83 \mathrm{~cm}^{2}$ por anel.

Relação Vt e Vr

Para determinar a relação entre volume total e o volume real (VT/VR) do meio suporte, utilizaram-se duas provetas de $1000 \mathrm{~mL}$, o (VR) foi determinado diretamente da leitura direta do volume remanescente em $\mathrm{P} 2$, resultando em $80 \mathrm{~mL}$. O volume de cada meio suporte de 16 $\mathrm{ml}$ em um volume total de 4,8 litros. Assim sendo, a relação VT/VR do meio suporte foi de 9:1.

Determinação da massa total e massa inicial

A massa total do meio suporte foi determinada por lotes de 10 anéis plásticos (10 repetições), secagem em estufa durante 3 horas, a $80^{\circ} \mathrm{C}$, e pesados na balança analítica (marca Sartorius, modelo BP221S), apresentando massa de 97,70 gramas, servindo de base para determinação da massa de lodo aderida ao meio suporte (biofilme).

\section{Determinação de eficiência}

Foram realizadas determinações da eficiência do sistema com relação à remoção de matéria orgânica. A unidade monitorada foi o filtro anaeróbio (FA).

\section{Determinação do $\mathrm{pH}$, alcalinidade, acidez}

Para determinação do $\mathrm{pH}$, utilizou-se um potenciômetro digital, aparelho da marca HACH, modelo Sension4, calibrado de acordo com o proposto pela APHA (1998).

A determinação da alcalinidade total foi feita por titulação com solução padronizada de $\mathrm{H}_{2} \mathrm{SO}_{4}$. A primeira fase da titulação era feita até o $\mathrm{pH}$ 5,75, (alcalinidade parcial (AP)). A segunda fase era titulada até o $\mathrm{pH}$ 4,3 (alcalinidade intermediária (AI)).

Para análise de acidez total media-se o pH e titulava-se com solução de hidróxido de sódio a $0,02 \mathrm{~N}$, até atingir $\mathrm{pH}$ de 8,3 , para total neutralização do gás carbônico presente na amostra.

$D Q O$

A demanda química de oxigênio (DQO) foi definida prevalecendo à metodologia de digestão ácida, concretizada em blocos digestores por um período de duas horas, a $140^{\circ} \mathrm{C}$. Foi empregado para a leitura, o espectrofotômetro modelo DR-2010 da marca Hach.

$D B O$

Para o procedimento da DBO, foi adicionada a uma solução de $500 \mathrm{~mL}$ de água destilada oxigenada, $1 \mathrm{~mL}$ de cada solução nutriente (cloreto de cálcio, cloreto férrico, solução tampão fosfato e sulfato de magnésio) e complementado o volume para $1 \mathrm{~L}$. Em triplicata, a solução foi transferida para os frascos de DBO. Realizou-se a leitura de um frasco (prova em branco) e dois restantes foram levados à incubação, a $20^{\circ} \mathrm{C}$, por 5 dias. A amostra foi então titulada com tiossulfato de sódio a $0,0125 \mathrm{~N}$.

\section{Análise de NTK, fósforo total, teor de sólidos}

As análises de Nitrogênio total Kjeldahl (NTK) e fósforo total (P) foram realizadas segundo as metodologias propostas por APHA (1998).

A determinação do teor de sólidos totais, fixos, voláteis, suspensos e dissolvidos foi realizada a partir da metodologia descrita por APHA (1995). Para cálculo de Sólidos totais fixos (STF), cadinhos com o resíduo da secagem anterior $\left(105^{\circ} \mathrm{C}\right)$ eram levados à mufla $\left(550{ }^{\circ} \mathrm{C}\right)$, onde permaneciam por 30 minutos. Os cadinhos eram levados ao dessecador, resfriados e pesados (P3). 
Os sólidos voláteis foram determinados pela diferença entre o P2 (sólidos totais) e P3 (sólidos fixos).

\section{Produção de biogás}

A produção de biogás foi determinada em função da carga orgânica. A correção do volume de biogás para condições de temperatura e pressão foi efetuada pelas equações sugeridas por Chenicharo (2007) e Campos et al. (2005b):

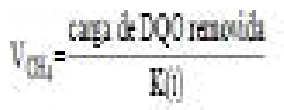

Onde:

$\mathrm{V}_{\mathrm{CH} 4}=$ volume de metano produzido (L);

$\mathrm{DQO}_{\mathrm{CH} 4}=\mathrm{DQO}$ removida no reator e convertida em $\mathrm{CH}_{4}$ (g DQO);

$\mathrm{K}(\mathrm{t})=$ fator de correção da temperatura operacional do reator $\left(\mathrm{g} \mathrm{DQO} \mathrm{L}^{-1}\right)$.

$k(t)=\frac{P \cdot \mathbb{Z}}{\text { R. }([-27 j)}$

onde:

$\mathrm{P}=$ pressão atmosférica local $(\mathrm{k} \mathrm{Pa})$;

$\mathrm{K}=\mathrm{DQO}$ correspondente a um mol de CH4 (64 g de DQO mol-1)

$\mathrm{R}=$ constante dos gases $\left(8064,4086 \mathrm{k} \mathrm{Pa} \mathrm{m}^{3} \mathrm{~mol}^{-1} \mathrm{~K}^{-1}\right)$

$\mathrm{T}=$ temperatura operacional do reator $(\mathrm{K})$

$P=P_{P} x e \frac{\| V R}{2}$

onde:

$\mathrm{P}=$ pressão corrigida $(\mathrm{k} \mathrm{Pa})$;

Po = pressão atmosférica ao nível do $\operatorname{mar}(98,1 \mathrm{k} \mathrm{Pa})$;

$\mathrm{M}=$ massa molar média do ar $\left(0,029 \mathrm{~kg} \mathrm{~mol}^{-1}\right)$;

$\mathrm{g}=$ constante gravitacional $\left(9,806 \mathrm{~m} \mathrm{~s}^{-2}\right)$;

$\mathrm{z}=$ altitude local $(\mathrm{m})$;

$\mathrm{R}=$ constante dos gases $\left(8064,4086 \mathrm{k} \mathrm{Pa} \cdot \mathrm{m}^{3} \mathrm{~mol}^{-1} \mathrm{~K}^{-1}\right)$

$\mathrm{T}=$ temperatura $(\mathrm{K})$

A DQO removida tem dois destinos, sendo a primeira inerente à produção do metano $\mathrm{e}$ outra à da biomassa, como representa a expressão:

$\mathrm{DQO}_{\text {biomassa }}=\mathrm{DQO}_{\text {removida }}-\mathrm{DQO}_{\mathrm{CH} 4}$

onde:

DQO ${ }_{\text {removida }}:$ DQO removida no processo $(\mathrm{kg})$

DQO ${ }_{\mathrm{CH} 4}$ : DQO utilizada para a produção do metano $(\mathrm{kg})$

DQO ${ }_{\text {Biomassa: }}$ : DQO utilizada para a produção da biomassa $(\mathrm{kg})$ 
A DQO utilizada para a produção da biomassa pode ser correlacionada com o coeficiente de crescimento bacteriano, resultando na Equação:

DQO Biomassa $=$ Y. DQO removida

Assim a DQO utilizada para a produção de $\mathrm{CH}_{4}$ pode ser dada segundo a seguinte equação:

DQO $\mathrm{CH} 4=$ DQO removida- DQO Biomassa

\section{Resultados e discussão}

\section{Variáveis do processo}

A vazão afluente relativa ao tratamento sofreu pequenas oscilações (Figura 2), provavelmente devido à proliferação de algas no sistema e entupimentos da bomba dosadora.

\section{Figura 2 - Valores da vazão afluente ao sistema de tratamento}

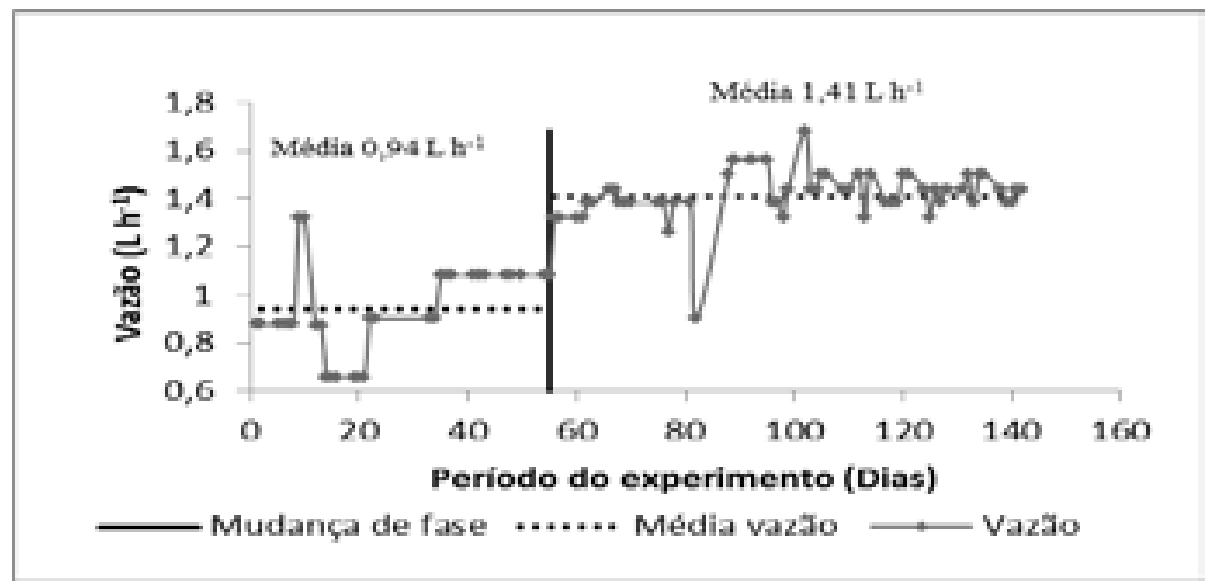

Fonte: próprio autor.

Determinação do $\mathrm{pH}$, alcalinidade, acidez

As variações da temperatura, do $\mathrm{pH}$, da alcalinidade, a relação $\mathrm{AI} / \mathrm{AP}$ no afluente e efluente e a acidez total do filtro anaeróbio estão apresentados na Figura 3.

Nota-se que a temperatura efluente do filtro anaeróbio variou muito pouco em relação ao afluente em ambas as fases do experimento. Em contrapartida, o mesmo não se pode dizer quando se compara as temperaturas entre as fases do experimento, pois na fase 1, a média encontrada da temperatura para o efluente foi de $27,4{ }^{\circ} \mathrm{C}$ e já, na fase 2 , o valor encontrado foi de $22,7{ }^{\circ} \mathrm{C}$, ocorrendo em média uma variação térmica entre as duas fases de $4,7^{\circ} \mathrm{C}$. Essa queda de temperatura foi provavelmente devido à entrada do outono. Os valores da fase 2 estão pouco abaixo do indicado para o tratamento de efluentes em processos anaeróbios que, de acordo com Metcalf e Eddy (2003), a temperatura ótima para que as reações ocorram de forma satisfatória, está na faixa mesofílica entre $25^{\circ} \mathrm{C}$ a $35^{\circ} \mathrm{C}$.

Segundo Chernicharo (2007) é importante que haja manutenção de uma temperatura uniforme no reator, uma vez que o processo anaeróbio é considerado sensível a mudanças de temperatura, podendo provocar falha do processo. As condições de temperatura têm importante efeito na seleção e crescimento dos microrganismos. Em reações enzimáticas pode vir a interferir na termodinâmica de reações, como a pressão de $\mathrm{H}_{2}$, nos quais a fermentação e produção de metano estejam ocorrendo (CHERNICHARO, 2007). 
Os valores de $\mathrm{pH}$, no transcorrer do experimento, foram estáveis, como pode ser observado na Figura 3C e 3D, até mesmo quando o sistema ficou sob cargas mais elevadas. O sistema demonstrou elevada capacidade de tamponamento harmonizando condições adequadas ao desenvolvimento do processo anaeróbio e eficiências na remoção de carga orgânica da água residuária de suinocultura.

A característica de tamponamento do $\mathrm{pH}$ na degradação anaeróbia se dá por meio da produção de $\mathrm{CO}_{2}$ e da decomposição de proteínas e outros substratos, constituindo a alcalinidade bicarbonato (RAMJEAWON, 2001). O valor médio do $\mathrm{pH}$ no afluente foi de 7,4 e efluente do filtro anaeróbio de 7,5 favorecendo o desempenho dos microrganismos produtores de metano que possuem crescimento ótimo, entre 6,5 e 7,5, conforme Chenicharo (2007).

No que concerne à estabilidade do processo, as bactérias produtoras de ácidos são menos sensíveis ao $\mathrm{pH}$ quando comparadas com as arqueas metanogênicas produtoras de metano. As bactérias acidogênicas conseguem ter bastante atividade em $\mathrm{pH}$ baixo, exibindo crescimento ótimo na faixa entre 5,0 e 6,0, com tolerância maior em valores mais baixos, até próximo a 4,5 (CHERNICHARO, 2007).

Os valores de $\mathrm{pH}$ no sistema de tratamento pesquisado favoreceram a microbiota, pois, segundo Jay (2005), o aumento da temperatura torna o meio mais ácido, e alterações bruscas de $\mathrm{pH}$ tornam as células mais sensíveis a grande variedade de agentes tóxicos, sendo as células mais jovens mais suscetíveis.

$\mathrm{O}$ efluente do FA manteve-se numa faixa de $\mathrm{pH}$ correspondente a 7,5 e 8,0, indicando possivelmente que a alcalinidade observada (Figura 3E e 3F) foi devida ao sistema carbônico. Segundo Speece (1996), para um grama de proteína que é degradada, 0,1 grama de $\mathrm{NH}_{4}{ }^{+}-\mathrm{N}$ é formado, o qual, complexado a bicarbonato de amônia, equivale a $0,36 \mathrm{~g} \mathrm{~L}^{-1} \mathrm{de} \mathrm{CaCO}_{3}$, sendo este processo vantajoso por serem de reatores anaeróbios tratando água residuária de suinocultura. 
Figura 3 - Variação da A. temperatura afluente; B. temperatura efluente; C. pH afluente; D. pH efluente; E. alcalinidade afluente; F. alcalinidade efluente; G. relação AI/AP no afluente e efluente e H. acidez total do filtro anaeróbio

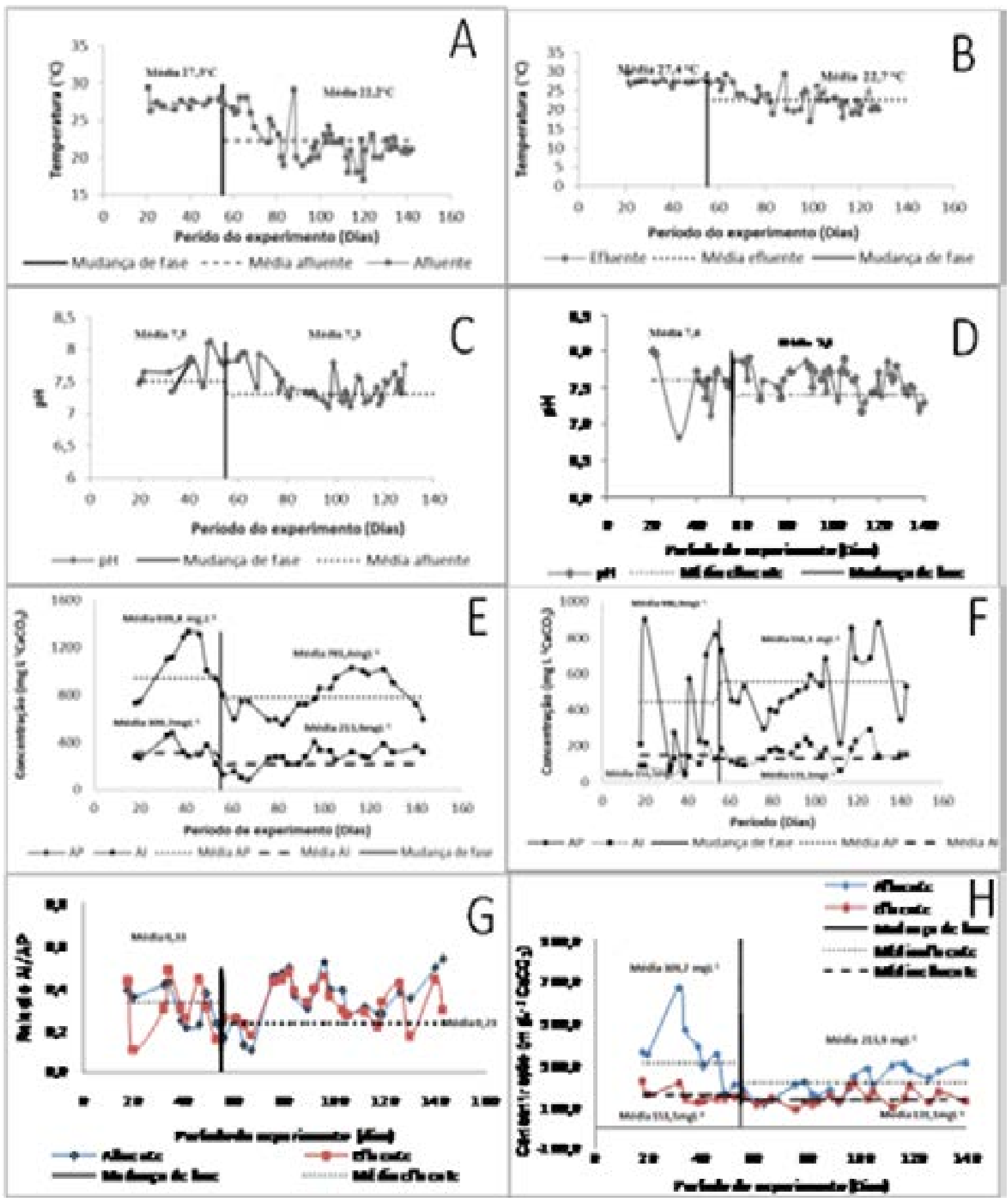

Fonte: próprio autor. 
Pode ser observado pelas curvas de alcalinidade (Figura 3E e 3F) que o desempenho da unidade anaeróbia foi instável, considerado maior ou menor grau de diluição da água residuária nos diferentes dias de coleta, proporcionando maior ou menor concentração de sólidos e, consequentemente, de proteínas no afluente do filtro anaeróbio, as quais são precursoras da alcalinidade bicarbonato. Metcalf e Eddy (2003) afirmam que, para que o processo de digestão anaeróbia ocorra de forma satisfatória, a alcalinidade total deverá situar-se na faixa de $1.000 \mathrm{a}$ $5.000 \mathrm{mg} \mathrm{L}^{-1}$ de $\mathrm{CaCO}_{3}$.

De acordo com Ripley et al. (1986), valores da relação AI/AP superiores a 0,3 indicam distúrbios no processo. No experimento, essa relação iniciou dentro do valor 0,3 , (Figura $3 \mathrm{G}$ ) e estes valores foram gradualmente diminuindo ao longo do tempo, até atingirem valores estáveis no fim da pesquisa. Essa tendência de estabilidade foi devido à aclimatização da biomassa. Os valores no afluente foram maiores que o efluente devido ao aumento de AI.

Pode ser observado que, com a diminuição do TDH durante a fase 2 ocorreram pequenas variações de AP e AI afluente do sistema. Segundo Oliveira (1997), com a diminuição do TDH também foram observadas diminuições nos valores de AI e AP, situação semelhante à que ocorreu neste trabalho. Vale mencionar que mesmo a AT encontrada sendo pequena, não interferiu no desempenho do processo anaeróbio quando observa que a AP mostrou-se elevada, 501,6 mg L-1 de bicarbonatos.

Pode-se observar baixa concentração de ácidos voláteis (Tabela 1). Seu aumento resultaria em desequilíbrio entre a fase de fermentação ácida e a metanogênese.

\section{Tabela 1 - Médias referentes à acidez volátil (AV), alcalinidade total e relação acidez volátil/alcalinidade total em $\mathrm{mg} \mathrm{L}^{-1}$ de $\mathrm{CaCO}_{3}$ do afluente e efluente do filtro anaeróbio}

\begin{tabular}{cccc}
\hline Unidade & AV (média) & AT (média) & AV/AT \\
\hline Afluente & 251,45 & 1142,84 & 0,22 \\
Efluente & 141,02 & 644,37 & 0,21 \\
\hline
\end{tabular}

A acidez volátil manteve-se no afluente em média de $251,45 \mathrm{mg} \mathrm{L}^{-1} \mathrm{e}$, no efluente do filtro anaeróbio, o valor foi reduzido para média de141,02 $\mathrm{mg} \mathrm{L}^{-1}$, resultando em 43,9\% no decréscimo destes ácidos no interior do sistema, evitando, assim, problemas com desequilíbrio entre a fase de fermentação ácida e a metanogênese. As metanobactérias utilizam os ácidos voláteis e, quando seus crescimentos se encontram inibidos, ocorre acúmulo de ácidos.

A AV, neste experimento, manteve-se dentro da faixa recomendada para reatores estáveis, tendo como média 141,02 mg. $\mathrm{L}^{-1}$ de ácidos voláteis. Conforme Campos et al. (2006), onde concentrações encontram-se acima de $150 \mathrm{mg} \cdot \mathrm{L}^{-1}$ de ácidos voláteis torna-se indício de que o sistema não está atuando em condições ótimas. Isso ocorre, mesmo antes de se observar alterações no pH. Rodrigues (2008); em experimentos com efluentes da suinocultura, também deparou com concentrações inferiores a $150 \mathrm{mg} . \mathrm{L}^{-1}$ de ácidos graxos voláteis, ou seja, menores que a concentração limite para a inibição da atividade metanogênica.

A Figura $3 \mathrm{H}$ vem ilustrar essa redução de ácidos voláteis totais do afluente quando passa pelo sistema anaeróbio de tratamento. Vale observar que os maiores valores de acidez ocorreram na primeira fase do processo, quando não havia ainda uma grande aclimatização da população bacteriana, responsável pelo consumo desses ácidos. 
A relação AV/AT se manteve com valor médio de 0,21 no efluente do filtro anaeróbio, ao longo de todo o experimento, dando uma condição estável para o sistema. O valor da relação considerado limite para a estabilidade do sistema de digestão anaeróbia deve ser de 0,5.

Não obstante, os ácidos voláteis são tóxicos para as bactérias metanogênicas somente em sua forma não ionizada, com o $\mathrm{pH}$ < 6 (ZEGERS, 1987). Uma vez que o $\mathrm{pH}$ do efluente da unidade de tratamento em estudo exibiu pouca variação, operando perto da neutralidade, entre 6,8 e 7,9, pode-se afirmar que os ácidos graxos estavam em grande quantidade ionizados, portanto, não tóxicos às bactérias metanogênicas. Portanto, o filtro anaeróbio demonstrou boas condições de tamponamento, o que, de acordo com Campos et al. (2006), é um fator importante quando se leva em consideração o custo de manutenção, pois a adição de substâncias químicas para tamponamento oneraria o processo.

$D B O, D Q O$ e eficiência de remoção

A concentração de $\mathrm{DBO}_{5}$ afluente apresentou valores entre 150 e $2375 \mathrm{mg} \mathrm{L}^{-1}$ (Figura 4A), com valor médio de $1036 \mathrm{mg} \mathrm{L}^{-1}$. Já a $\mathrm{DBO}_{5}$ efluente do $\mathrm{FA}$ apresentou valor médio de $281 \mathrm{mg}$ $\mathrm{L}^{-1}$ (Figura 4B), resultando numa eficiência de 72,8\% de remoção. Os valores máximos de DBO afluente e efluente exibiram variações devido às oscilações da composição dos dejetos e sua diluição.

Todavia, observando a variação da concentração efluente do FA, constata-se que o mesmo não pode ser lançado em um corpo de água receptor, por não atender os padrões de lançamento estabelecidos pela deliberação normativa do COPAM/CERH-MG n. ${ }^{\circ}$ 1, de 05 de maio de 2008, sendo necessário pós-tratamento para melhor polimento. Os valores correspondentes a essa grande oscilação na concentração de $\mathrm{DBO}_{5}$ apresentou elevado coeficiente de variação (59\%), o que ocasiona variações nos resultados.

A variação da eficiência de remoção na fase 2 , ocorrido no $64^{\circ}$ dia, foi justificado pelo emprego de menor TDH, resultando na perda de biomassa por varredura, menor contato entre biomassa e substrato e possível desestruturação da biomassa dispersa ou floculada, diminuindo a eficiência. 
Figura 4 - Variação nos valores de DBO A. DBO afluente; B. DBO efluente C. DQO filtrada; D. eficiência da DQO filtrada e bruta no afluente e efluente; E. variação da concentração de NTK e F. fósforo do filtro anaeróbio durante o experimento

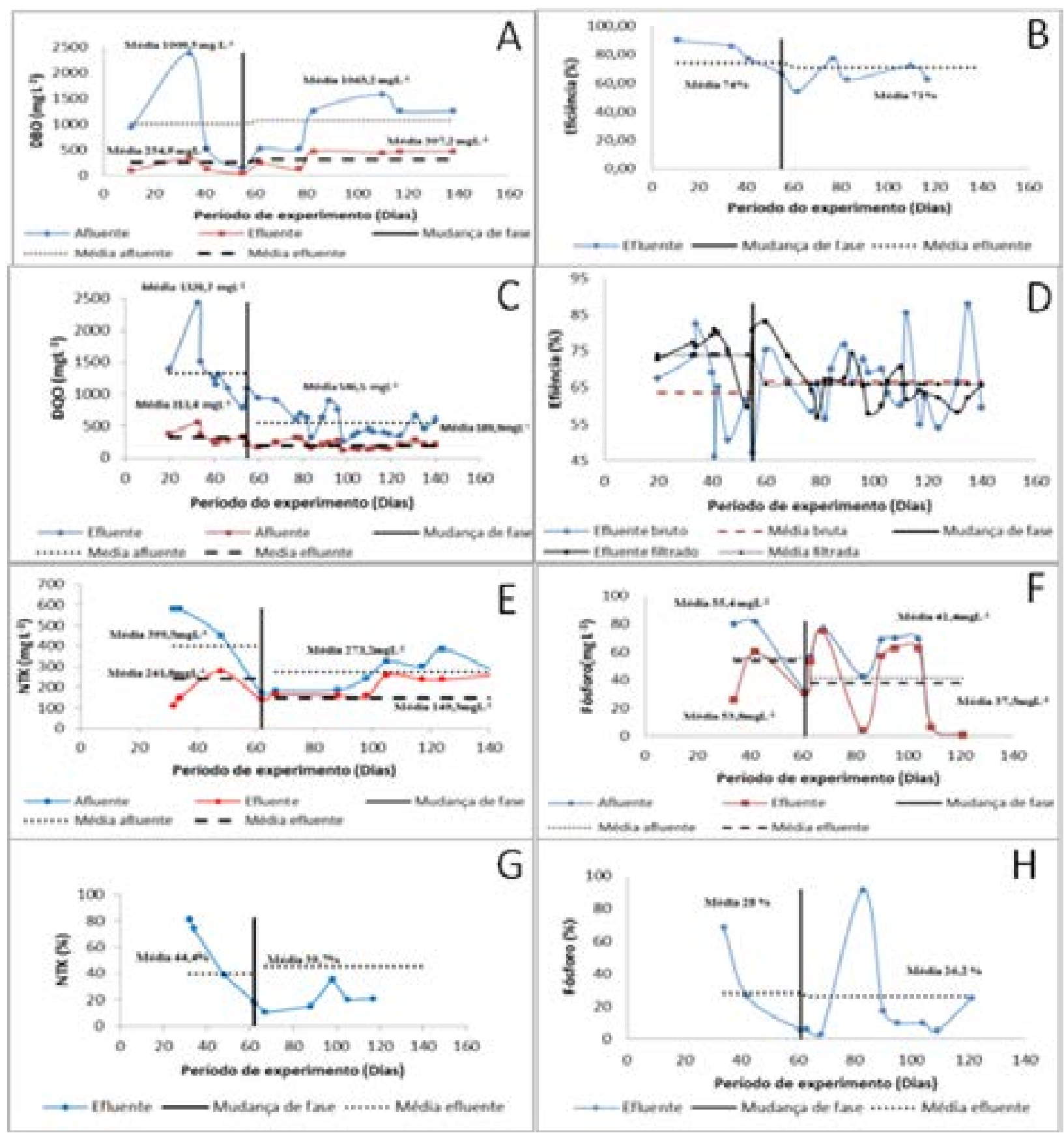

Fonte: próprio autor.

Os valores médios de $\mathrm{DBO}$ encontrados durante este estudo são semelhantes aos encontradas por Campos et al. (2005b), trabalhando em escala laboratorial e por Costa (2007), operando um reator em escala piloto. Esses autores encontraram valores efluentes de 457 e 381 mg L ${ }^{-1}$ de DBO, respectivamente. Já Lourenço (2006), analisando águas residuárias de suínos em reatores de bancada, obteve $67 \%$ de eficiência, na remoção da DBO. 
Os valores de $\mathrm{DQO}{ }_{\text {total }}$ no sistema oscilaram ao longo do tempo, devido à diluição do efluente, sendo encontrados valores mais elevados e maior variação na fase1 (Figura 4B), quando o FA operou com TDH de 94,7 h. O valor médio de DQO durante este período foi de 1506,9 $\mathrm{mg} \mathrm{L} \mathrm{L}^{-1}$ no afluente, apresentando uma eficiência de remoção média de $63 \%$. Para a fase 2 , ainda com um TDH reduzido de 63,1 h, o sistema apresentou uma eficiência ainda mais significativa para a remoção de matéria orgânica, chegando à média de 66\%, mostrando que o aumento foi ocasionado pela característica do efluente da suinocultura durante aquele período, como pode ser visualizado na Tabela 2 .

Tabela 2 - Variação da concentração de matéria orgânica e eficiência de remoção

\begin{tabular}{|c|c|c|c|c|c|}
\hline & Unidade & $\begin{array}{c}\text { Média } \\
\left(\mathrm{mg} \mathrm{L}^{-1} \mathrm{DQO}\right)\end{array}$ & $\begin{array}{c}\text { TDH } \\
\text { (h) }\end{array}$ & $\begin{array}{c}\mathrm{COV}\left(\mathrm{kg} \mathrm{m}^{-3} \mathrm{~d}^{-1}\right. \\
\text { DQO }\end{array}$ & Eficiência (\%) \\
\hline Fase 1 & $\begin{array}{l}\text { Afluente } \\
\text { Efluente }\end{array}$ & $\begin{array}{c}1506,90 \\
507,30\end{array}$ & 94,72 & $\begin{array}{l}0,41 \\
0,14\end{array}$ & 63,65 \\
\hline Fase 2 & $\begin{array}{l}\text { Afluente } \\
\text { Efluente }\end{array}$ & $\begin{array}{l}897,20 \\
290,30 \\
\end{array}$ & 63,14 & $\begin{array}{l}0,34 \\
0,11 \\
\end{array}$ & 66,64 \\
\hline
\end{tabular}

Quanto à $\mathrm{DQO}_{\text {filtrada, }}$ o comportamento foi semelhante à $\mathrm{DQO}_{\text {bruta }}$ (Figura 4D). Isto evidencia uma boa retenção de sólidos, por meio de mecanismos físicos, proporcionados pelo meio suporte e pelo processo de sedimentação.

Os resultados em termos de remoção da DQO filtrada, mostram que a estabilização complementar da matéria orgânica no efluente ocorre por via bioquímica (hidrólise, acidificação e metanogênese), e não apenas por mecanismos físicos. Os valores para a DQO total e filtrada (Tabela 3) também apresentaram padrão de remoção semelhante aos de DBO. Para a DQO filtrada, a eficiência de remoção foi maior, em média de 71\%, apresentando-se mais constante, ao longo do experimento, principalmente, após o $73^{\circ}$ dia.

É possível observar que houve elevação do valor da DQO na partida do sistema (fase 1) que, apesar de estar operando com um TDH 33,37\% maior que o da fase 2, recebeu uma COV de $0,41 \mathrm{~kg}$ DQO m $\mathrm{m}^{-3} \mathrm{~d}^{-1}$, correspondente a uma carga $17,08 \%$ maior que a empregada na fase 2 ( 0,34 kg DQO m $\left.{ }^{-3} \mathrm{~d}^{-1}\right)$ que operou com TDH de 63,1 h. Esta diferença de COV é justificada pelas práticas de limpeza nas baias e consequente diluição excessiva do efluente, ocasionando numa menor quantidade de matéria orgânica a ser tratada (fase 2).

É interessante ressaltar que, embora a maior carga orgânica tenha sido aplicada durante a partida do sistema, este apresentou alta estabilidade e eficiência de remoção desde os primeiros dias, variando pouco quando comparado com a fase 2 em termos de remoção de DQO. A eficiência da fase 1 foi de $63,6 \%$, operando com uma vazão média de $0,94 \mathrm{~L} \mathrm{~h}^{-1}$, enquanto na fase 2 essa eficiência teve um aumento de 3\% em média comparada com a fase 1.

Monroy et al. (1994) encontraram resultados semelhantes, avaliando filtro anaeróbio em escala-piloto para tratar efluente da indústria de sorvete com carga orgânica de 5,5 $\mathrm{kg} \mathrm{m}^{-3} \mathrm{~d}^{-1} \mathrm{DQO}$ e obteve remoção de $75 \%$ de DQO. Os valores para DQO total também foram semelhantes aos encontrados por Campos et al. (2005b), trabalhando em escala laboratorial de $1.755 \mathrm{mg} \mathrm{L}^{-1}$ e Costa (2007) em escala piloto de1.897 $\mathrm{mg} \mathrm{L}^{-1}$, para DQO total . 
A eficiência do sistema na remoção da DQO total e filtrada, de modo global, foi de $67 \%$ e 70\%, respectivamente, considerado os valores iniciais de 1086,4 e 791,9 $\mathrm{mg} \mathrm{L}^{-1}$. Os valores de eficiência de DQO total e filtrada podem ser observados na Tabela 3.

\section{Tabela 3 - Valores médios de DQO total e filtrada e eficiência média de remoção na unidade do sistema de tratamento de efluente, obtidos durante o período experimental}

\begin{tabular}{ccc}
\hline & DQO total $\left(\mathbf{m g ~ L}^{-\mathbf{1}}\right)$ & DQO filtrada $\left(\mathbf{m g ~ L}^{\mathbf{- 1}}\right)$ \\
\hline Afluente & 1086,45 & 791,92 \\
Efluente & 357,64 & 233 \\
Eficiência (\%) & 67 & 71 \\
\hline
\end{tabular}

Observou-se redução de DQO, porém não se atingiram valores solicitados pela legislação de $180 \mathrm{mg} \mathrm{L}^{-1}$ DQO (CONAMA, 2008).

Cabe mencionar que, para a maior parte dos despejos orgânicos, é presumível correlacionar a DQO com a DBO e essa relação DBO/DQO indica o grau de biodegradabilidade dos efluentes. Em conformidade com Braile e Cavalcante (1993), os parâmetros de DQO e DBO podem ser ponderados para uma interpretação inicial e de direcionamento no desígnio dos possíveis tratamentos. Valores elevados indicam que a fração biodegradável é elevada e valores baixos advertem que a fração inerte é elevada. Para esgotos domésticos, a relação entre DBO/DQO varia entre 0,3 e 0,8 , sendo o valor médio de 0,5 .

\section{Análise de NTK, fósforo total, teor de sólidos}

Os valores médios analisados de NTK, no afluente e efluente do FA, foram de 336,2 e 195,5 $\mathrm{mg} \mathrm{L}^{-1}$ (Figura 4E), os quais estão abaixo dos observados por Kunz (2005). Não obstante, Diesel et al. (2002) ponderaram que a concentração de N, P e K nos estercos animais está pautada com a qualidade dos alimentos ingeridos e com o tamanho do animal.

Nota-se que os valores médios de NTK decresceram no afluente e efluente do FA, atingindo valor mínimo de $108,8 \mathrm{mg} \mathrm{L} \mathrm{L}^{-1}$, sendo observada maior variação na fase 1 onde a coleta das amostra foi realizada de forma pontual. Este fato ainda pode ser justificado pela quebra e consumo de proteínas por microrganismos na unidade de tratamento em ambas as fases.

Os valores médios de $\mathrm{P}$ durante o experimento no afluente e efluente do FA foram de 53,1 e 39,8 mg L ${ }^{-1}$, respectivamente (Figura 4F). Segundo Chenircharo (2007), a baixa eficiência de nutrientes como o fósforo é uma das desvantagens do filtro anaeróbio, sendo necessária aplicação de pós-tratamento.

Flutuações mais acentuadas podem ter sido causadas no primeiro momento, por terem sido coletadas amostras simples. Oscilações da concentração de matéria orgânica também poderiam ter influenciado, uma vez que o acúmulo de fósforo na unidade de tratamento vem do processo de quebra de proteínas ou, ainda, devido à morte de células antigas (SOUSA, 1996).

$\mathrm{O}$ requerimento de $\mathrm{P}$ pode ser estimado como $1 / 5$ a $1 / 7$ do requerimento de $\mathrm{N}$ (CHERNICHARO, 2007). No experimento, foi encontrada a relação média de 5:1, resultado que implica uma quantidade de $\mathrm{P}$ no limite necessário.

A eficiência na remoção NTK e $\mathrm{P}_{\text {total }}$, alcançou valores de $33 \%$ e $24 \%$, respectivamente, semelhantes aos encontrado por Campos et al. (2006). Os autores obtiveram eficiências de 
remoção de NTK e $\mathrm{P}_{\text {total }}$ de $41 \%$ e 36\%, operando sistema em escala laboratorial, com efluente de suinocultura de ST de $2.490 \mathrm{mg} \mathrm{L}^{-1}$.

As mais baixas eficiências observadas no efluente do filtro anaeróbio se deram na fase 2 onde o TDH foi um pouco reduzido, podendo ter proporcionado pouco tempo para o desenvolvimento de compostos complexos cristalinos como a hidroxiapatita.

No afluente e efluente do FA, as concentrações médias de ST, STF e STV foram 158; 693 e $902 \mathrm{mg} \mathrm{L}^{-1}$ e 1112; 544 e $546 \mathrm{mg} \mathrm{L}^{-1}$ respectivamente, com eficiências médias de 29,9, 21,5 e $37,4 \%$, como pode ser visto na Tabela 4 , ocorrendo variações de comportamento durante a pesquisa.

\section{Tabela 4 - Concentração dos sólidos no afluente e efluente e as respectivas eficiências no sistema de tratamento}

\begin{tabular}{cccc}
\hline \multirow{2}{*}{ Unidade } & \multicolumn{3}{c}{ Sólidos $\left(\mathbf{m g ~ \mathbf { ~ L } ^ { - 1 } )}\right.$} \\
\cline { 2 - 4 } & Totais & Fixos & Voláteis \\
\hline Afluentes & 1585,62 & 693,26 & 902,02 \\
Efluentes & 1112,50 & 544,01 & 564,78 \\
Eficiência & 29,9 & 21,5 & 37,5 \\
\hline
\end{tabular}

Em geral é observada a baixa eficiência de ST, SF e SV resultando baixa remoção de matéria orgânica e interferência na produção de biogás. A eficiência média de remoção de sólidos orgânicos e inorgânicos no FA foi abaixo de 50\%, já que a maior parte dos sólidos grosseiros foi removida na peneira estática, logo depois o restante reteve-se no TAE que funcionou como decantador primário ao FA. Assim o afluente do filtro continha sólidos mais dissolvidos, contribuindo com a formação de um lodo de boa qualidade, permitindo boa sedimentação.

A baixa eficiência para a remoção de sólidos fixos deve-se à característica deste material sofrer alterações pequenas em relação a sua concentração inicial quando submetido a sistemas biológicos de tratamento.

Segundo Campos et al. (2004), a eficiência na remoção de sólidos presentes nos efluentes é devida a materiais de fácil biodegradação, como proteínas, açúcares, lipídios, entre outros. Nota-se que o efluente tratado foi constituído, em sua maioria, de material de fácil degradação, em função dos valores mais significativos de sólidos totais voláteis comparados aos sólidos totais fixos. Segundo Leite (1997), para resíduos com percentuais maiores de sólidos voláteis totais, haverá maior acréscimo na taxa de produção de gás metano, pois os sólidos totais voláteis são constituídos apenas de matéria orgânica.

Vale ressaltar que além das variações intrínsecas ao efluente em função do manejo distinguido na granja, no que concerne ao tempo de lavagem das baías influenciando diretamente na diluição do efluente para as diferentes coletas. Há também que se considerar o arraste de lodo, ocorrido, principalmente, na última etapa da avaliação, quando o sistema foi operado com vazão da ordem de $1,4 \mathrm{~L} \mathrm{~h}^{-1}$ correspondente a uma carga hidráulica de $0,38 \mathrm{~m}^{3} \cdot \mathrm{m}^{-3} \cdot \mathrm{d}^{-1}$ que, associada à presença de óleos e graxas, podem ter ocasionado arraste de lodo.

Há ainda outro fator que poderia facilitar o arraste de lodo, como a velocidade do líquido na entrada do reator, devido ao reduzido diâmetro da tubulação causando turbulência no leito de lodo, facilitando o arraste e o transporte de partículas do leito. Além disso, a produção de biogás, aliada à velocidade ascensional do líquido, que proporciona grau de mistura no interior do reator, pode causar desprendimento (cisalhamento) e o subsequente carreamento do lodo de menor 
densidade, que inicialmente se apresentava preso nos interstícios formados pelo agrupamento de material inerte do meio suporte.

Campos et al. (2005a), operando reator UASB com água residuária de suinocultura, em escala de bancada com TDH de 30 horas e concentração média de SVT de $1.240 \mathrm{mg} \mathrm{L} \mathrm{L}^{-1}$, observaram eficiência de $73,2 \%$ de remoção. Os valores de eficiência de remoção desses SVT encontrados nesta pesquisa foram inferiores, chegando a média de 37,5\%.

O efluente da granja de suínos passava pelas unidades de tratamento preliminar: caixa de areia e peneira estática e retinham os sólidos em suspensão grosseiros. Parte significativa desses SS é representada pela matéria orgânica no meio líquido, desta forma, o processo de sedimentação no TAE foi capaz de diminuir a carga de DBO encaminhada ao tratamento secundário.

A pressão atmosférica local foi de $0,901 \mathrm{~atm}$, a temperatura média do líquido no $\mathrm{FA}$ foi de $24,7{ }^{\circ} \mathrm{C}$ e o valor da correção da temperatura local $\mathrm{K}(\mathrm{t})$, igual a 2,357 $\mathrm{g} \mathrm{L}^{-1} \mathrm{DQO}$. $\mathrm{K}(\mathrm{t}) \frac{0,901 \times 6 \mathrm{6}}{0,08206 \times 297,7}=2,357 \mathrm{~g} \mathrm{~L}^{-1}$. De posse desses valores e considerando o coeficiente de crescimento bacteriano médio de 0,34 mg DQO mg SVT-1 $\mathrm{d}^{-1}$ determinado por Saleh (2004) para reatores anaeróbios operando com água residuária de suinocultura e ainda utilizando a DQO removida, determinou-se a parcela usada tanto para o crescimento da biomassa, como para a produção de biogás. A Tabela 5 mostra as médias das frações de $\mathrm{DQO}_{\text {Removida; }} \mathrm{DQO}_{\text {Biomassa e }} \mathrm{DQO} \mathrm{CH}_{\mathrm{CH}}$.

\section{Tabela 5 - Parâmetros referentes à DQO removida, utilizada para produção de biomassa e para produção de metano de efluente de suinocultura utilizada na produção de biogás}

\begin{tabular}{cc}
\hline Parâmetros & Efluente Filtro Anaeróbio \\
\hline Coef. Crescimento bacteriano $(\mathrm{Y})^{*}$ & 0,34 \\
DQO média removida $\left(\mathrm{mg} \mathrm{L}^{-1}\right)$ & 728,8 \\
DQO média biomassa $\left(\mathrm{mg} \mathrm{L}^{-1}\right)$ & 246,3 \\
DQO média $\mathrm{CH}_{4}\left(\mathrm{mg} \mathrm{L}^{-1}\right)$ & 482,4 \\
\hline
\end{tabular}

${ }^{*} m g m^{-1} d^{-1}$ na forma de $[D Q O]^{-1}[S V T]^{-1}[d]^{-1}$

Produção de biogás

Como a remoção de DQO total no experimento foi de $728,8 \mathrm{mg} \mathrm{L^{-1 }}$. A parcela da DQO removida utilizada para o crescimento bacteriano foi de $246,3 \mathrm{mg} \mathrm{L}^{-1} \mathrm{DQO}_{\text {total }}$ de efluente estabilizado. Considerou-se que a parcela restante da DQO removida tenha sido utilizada para

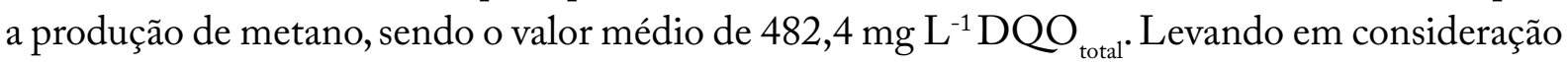
que a composição do biogás conforme Campos et al. (2005b) é em média, $60 \%$ de $\mathrm{CH}_{4}$ e $40 \%$ de $\mathrm{CO}_{2}$ e traços de gases, que podem ser desprezados, a produção teórica de metano no FA 0,205 L, levando a uma produção teórica de biogás de 0,344 L.

\section{CONCLUSÕES}

O sistema de tratamento anaeróbio em dois estágios foi eficiente na remoção de DQO e sólidos suspensos, possibilitando nas condições operacionais impostas, alcançar valores médios acima de $72 \%$ em condições estáveis de produção de metano e concentrações de alcalinidade e ácidos voláteis totais. A maior parte da remoção de matéria orgânica, sólidos suspensos, macro e micronutrientes e coliformes ocorreu no reator. Os estudos realizados permitem observar a importância da aplicação de reator anaeróbio e filtro anaeróbio para o tratamento de rejeitos, 
tal fato juntamente com a necessidade de promover a prática do desenvolvimento. O sistema adotado demonstrou eficiência em escala piloto, sobretudo na remoção de matéria orgânica, com valores de remoção de $67 \%$, confirmando sua viabilidade no controle de poluição hídrica. Dentro deste contexto, fomentar e difundir a utilização de fontes alternativas de energia para a geração de renda é uma ferramenta essencial para conscientizar os produtores deste ramo quanto à relevância de se realizar um tratamento adequado dos resíduos em suas propriedades, visando reduzir os impactos inerentes à prática desta atividade.

\section{REFERÊNCIAS}

AMERICAN PUBLIC HEALTH ASSOCIATION. Standard methods for the examination of water and wastewater. 20. ed. Washington: APHA, 1998. 1162 p.

AMERICAN PUBLIC HEALTH ASSOCIATION. Standard methods for the examination of water and wastewater. 19. ed. New York: APHA, 1995.

BITTON, G. Wastewater microbiology. New York: Wiley-Lyss, 1994. p. 478.

BLANES-VIDAL, V.; HANSEN, M. N.; ADAMSEN, A. P. S.; FEILBERG, A.; PETERSEN, S. O.; JENSEN, B. B. Characterization of odor released during handling of swine slurry: part I. relationship between odorants and perceived odor concentrations. Atmospheric Environment. Oxford, v.43, n.32, p.2997-3005, 2009.

BRAILE, P.M.; CAVALCANTI,J.E.W.A.Manual de tratamento de águas residuárias industriais. São Paulo: CETESB, 1993. 764 p.

CABRAL, J. R.; FREITAS, P. S. L.; REZENDE, R.; MUNIZ, A. S.; BERTONHA, A. Impacto da água residuária de suinocultura no solo e na produção de capim-elefante. Revista Brasileira de Engenharia Agrícola e Ambiental, Campina Grande, v.15, n.8, p.823-831, 2011.

CAMPOS, C. M. M.; LUIZ, F. A. R.; BOTELHO, C. G.; DAMASCENO L. H. S. Avaliação da eficiência do Reator UASB Tratando Efluente De Laticínio Sob Diferentes Cargas Orgânicas. Ciência e Agrotecnologia, Lavras, v.28, n.6, p.1376-1384, 2004.

CAMPOS, C.M.M.; CARMO, F. R. do; BOTELHO, C. G. Desenvolvimento e operação de reator anaeróbio de manta de lodo (UASB) no tratamento dos efluentes da suinocultura em escala laboratorial. Ciência e Agrotecnologia, Lavras, v.30, n.1, p.140-147, 2006.

CAMPOS, C. M. M.; DAMASCENO, L. H. S.; MOCHIZUKI, E.T.; BOTELHO, C. G. Avaliação do desempenho do reator anaeróbio de manta de lodo (UASB) em escala laboratorial na remoção da carga orgânica de águas residuárias da suinocultura. Ciência e Agrotecnologia, Lavras, v.29, n.2, p.390-399, 2005a. 
CAMPOS, C. M. M.; MOCHIZUKI, E. T.; DAMASCENO, L. H. S.; BOTELHO, C. G. Avaliação do potencial de produção de biogás e da eficiência de tratamento do reator anaeróbio de manta de lodo (UASB) alimentado com dejetos de suínos. Ciência e Agrotecnologia, Lavras, v.29, n.4, p.848-856, 2005b.

CHERNICHARO, C. A. de L. Reatores anaeróbios. In: Princípios do tratamento biológico de águas residuárias. 5 . Ed. CHERNICHARO, C. A. de L (ed). Belo Horizonte: DESA/UFMG,1997.

CHERNICHARO, C. A. L. Reatores anaeróbios: Princípios do tratamento biológico de águas residuárias. Belo Horizonte: Politécnica, 2007.379 p.

CONSELHO NACIONAL DO MEIO AMBIENTE - CONAMA. Resolução n. 257, de 17 de março de 2008. Dispõe sobre a classificação dos corpos de água e diretrizes ambientais para o seu enquadramento, bem como estabelece as condições e padrões de lançamento de efluentes. Disponível em: <http://www.mma.gov.br/port/conama/res/ res05/res35705.pdf>. Acesso: 10 maio 2014.

COSTA, C. C. Avaliação de sistema anaeróbio (RAC-UASB) no tratamento de água residuária de suinocultura e aplicação via fertirrigação, em feijão-vagem cultivado em ambiente protegido. 2007. 173 f. Tese (Doutorado em Engenharia de Água e Solo) Universidade Federal de Lavras, Lavras, 2007.

DIESEL, R.; MIRANDA, R. C.; PERDOMO, C. C. Coletâneas de tecnologia sobre os dejetos de suínos. Concórdia, SC: EMBRAPA-CNPSA/EMATER-RS, 2002.31 p. Boletim informativo.

GRADY,C.P.L.J.; LIM, H.C. Biological wastewater treatment: theory and applications. New York: Marcel Dekker, 1980. 963 p.

HAANDEL, A. O.; LETTINGA, O. Tratamento anaeróbio de esgotos: um manual para regiões de clima quente. Campina Grande: Epgraf, 1994. 239 p.

HENLEY, E. J.; SEADER, J. D. Separation Process Principles. 2. ed. Hoboken: John Wiley \& Sons, 2005, 817 p.

JAY, M. J. Microbiologia de alimentos. 6. ed. São Paulo: Artmed, 2005.

KUNZ, A. Impactos sobre a disposição de dejetos de animais sobre a qualidade e água superficiais e subterrâneas. Concórdia: Embrapa Suínos e Aves, 2005. 6 p.

LEITE, V.D. Processo de tratamento anaeróbio de resíduos sólidos urbanos inoculados com lodo de esgoto industrial. 1997. 250 f. Tese (Doutorado em Engenharia) Universidade de São Paulo, São Carlos, 1997. 
LOURENÇO, A. M. P. Desempenho de um sistema composto de reator UASB, filtro anaeróbio e lagoa aerada facultativa para o tratamento das águas residuárias da suinocultura.2006.129 f. Dissertação (Mestrado em Engenharia Agrícola) - Universidade Federal de Lavras, Lavras, 2006.

METCALF, L.; EDDY, P. A. Wastewater engineering: treatment, disposal, reuse. 4. ed. New York: McGraw-Hill, 2003. 1819 p.

MONROY, O.; JOHNSON, K. A.; WHEATLEY, A. D.; HAWKES, F.; CAINE, M. The anaerobic filtration of dairy waste: results of a pilot trial. BioresourceTechnology, v.50, n.3, p.243-251, 1994.

OLIVEIRA, K. R. F. de. Processos ecotecnológicos no tratamento de efluentes líquidos de fecularia. 2007. $111 \mathrm{f}$. Dissertação (Mestrado em Tecnologias Ambientais) - Universidade Federal do Mato Grosso do Sul, Campo Grande, 2007.

RAMJEAWON, T. A. Modeling approach for determining the alkalinity requirement for the treatment of weakly buffered carbohydrate industrial wastewaters by the UASB process. In:WORLD CONGRESS ANAEROBIC DIGESTION, 9., 2001, Antuérpia. Proceeding... Antuérpia: Technological Institute, 2001. v.2, p.571-574.

RIPLEY,L.E.; BOYLE,W.C.; CONVERSE J. C. Improved alkalimetric monitoring for anaerobic digestion of higt-strengt wastes. Journal Water Pollution Control Federation, Alexandria, v.8, n.5, p.406-411, 1986.

RODRIGUES, L. S. Concepção e avaliação de sistema de tratamento com reator anaeróbio de manta de lodo (UASB) e lagoa de polimento para águas residuárias de suinocultura. 2008.151 f. Tese (Doutorado em Ciência Animal) - Universidade Federal de Minas Gerais, Belo Horizonte, 2008.

SALEH, B. B. Parâmetros cinéticos de reatores anaeróbios de manta de lodo (UASB) operando com efluentes líquidos agroindustriais. 2004. 66 f. Dissertação (Mestrado em Construções Rurais e Ambiência) - Universidade Federal de Lavras, Lavras, 2004.

SOUSA, J. T. Pós tratamento de efluente de reator anaeróbio seqüencial em batelada e coluna de lodo anaeróbio para desnitrificação. 1996. 258 f. Tese (Doutorado em Engenharia Agrícola) - Universidade de São Paulo, São Paulo, 1996.

SPEECE, R. E. Anaerobic biotechnology for industrial wastewaters. Nashville: Vanderbilt University, 1996. 394 p.

ZEGERS, F. Anaerobic treatment of the wine drawn. In: UNIVERSIDAD DEL VALLE. Manual del curso del arranque y operacion de sistemas de flujo ascendente com manto de lodo. Santiago de Cali: UASB, 1987. 